\title{
Pengembangan Media Sosialisasi Nilai Kesenian Dongkrek Berbasis Multimedia Powerpoint
}

\author{
Dhimas Ardian Priambodo $\bowtie$, Universitas PGRI Madiun. \\ Muhammad Hanif, Universitas PGRI Madiun.
}

\section{$\bowtie \underline{\text { dhimasardian31@gmail.com }}$}

\begin{abstract}
Abstrak: Sosialisasi diperlukan sebagai peranan menanam atau mentransfer nilai kebiasaan dari satu generasi ke generasi lainnya. Tujuan penelitian ini adalah untuk mengembangkan media sosialisasi nilai kesenian Dongkrek melalui Komik Multimedia Power Point yang cocok untuk membentuk sikap berperilaku yang sesuai dengan perilaku dan kebudayaan yang dijunjung tinggi pada siswa. Penelitian ini dilaksanakan selama Sembilan bulan dengan menggunakan metode Research and Development R\&D. Uji teori menggunakan penilaian ahli dan praktisi. Media komik berbasis multimedia dengan subtantif dan fleksibilitas struktur desain model berkategori tinggi, valid, dan layak digunakan menurut para ahli materi, ahli bahasa dan ahli media, dengan persentase kelayakan komponen isi 97,5\% termasuk kriteria sangat layak, komponen kebahasaan 80\% dengan kriteria layak dan komponen penyajian 90\% dengan kriteria sangat layak. Persentase aktivitas siswa pertemuan I sebesar $82.5 \%$ dan sebesar $85.5 \%$ termasuk kriteria sangat baik. Pengujian juga menggunakan wawancara, observasi dan dokumentasi. Simpulan penelitian ini yaitu media komik berbasis multimedia dengan powerpoint layak digunakan pada pengenalan kesenian dongkrek efektif untuk digunakan pada pembelajaran siswa.
\end{abstract}

Kata Kunci: Kesenian Dongkrek; Multimedia PowerPoint

Abstract: Socialization is needed as the role of planting or transferring customs values from one generation to another. The purpose of this studi is develop media socialization of art values dongkrek through multimedia powerpoint comics suitable to from attitudes behaving in accordance with the behavior and culture are upheld in elementary school student. This study was conducted over nine months using the method Research and Development R\&D. The theories expert judgment and practitioners. Multimedia-based comic media with substantive and flexible structural design models are categorized high, valid, and feasible to be used according to material experts, with a $95,5 \%$ component content feasibility percentage including criteria very feasible, linguistic components $85 \%$ feasible and a $90 \%$ presentation component with very reasonable criteria. The test is also uses interviews, observation, and documentation. The conclusion of this research based comic media with a decent power point used in the introduction of effective dongkrek art to be used on learning leraners.

Keywords: Dongkrek Art ; Multimedia Powerpoint

Citation: Priambodo, D.A. \& Hanif, M. (2022). Pengembangan media sosialisasi nilai kesenian dongkrek berbasis multimedia powerpoint. Wewarah: Jurnal Pendidikan Multidisipliner, 1(1), 10 - 17. 


\section{PENDAHULUAN}

Sosialisasi merupakan proses penanaman atau transfer kebiasaan atau nilai dan aturan dari satu generasi ke generasi lainnya dalam sebuah kelompok atau masyarakat. Kesenian merupakan salah satu bagian yang esensi dari kebudayaan suatu masyarakat. Kasenian akan saling berelasi dengan sistem religinya, sistem bahasanya, sistem ekonominya, maupun sistem organisasinya. Perkembangan kesenian memiliki sifat yang hampir sama dengan perkembangan dinamika suatu kebudayaan manusia. Menurut Aristotle dalam Hajar Pamadhi (2012:43) "Ciri khas seni adalah mengupas alam dari hakikat yang sebenarnya, menurunkan manusia dan meninggikannya". Kebudayaan juga memiliki sifat yang dinamis dalam proses perkembangannya. Nilai dalam kesenian dongkrek (1)adanya nilai ketuhanan yang dimaksud disini adalah sebagai manusia harus ingat dari mana kita berasal dan antinya akan kemana setelah mati, (2) nilai budaya atau konsep mengenai apayang hidup dalam pikiran masyarakat Indonesia utamanya, mengenai apa yang dianggap memiliki nilai berharga dan penting dalam hidup, (3)Filosofi yang terkandung dalam kesenian dongkrek tak terhingga,(4) Etika sebagai ilmu yang mengajarkan manusia mendidik kearah tingkah laku yang lebih baik,(5)Keindahan atau estetika batasan keindahan itu sulit dirumuskan. Karena keindahan itu abstrak, identik dengan kebenaran. Komik merupakan suatu bentuk kartun yang mengungkapkan karakter dan memerankan suatu cerita dalam urutan yang erat dihubungkan dengan gambar dan dirancang untuk memberikan hiburan dan pengetahuan bagi pembacanya (Sudjana, dan Rivai, 2013:63).

Untuk mengatasi permasalahan supaya dapat dikaji secara mendalam maka diperlukan pembatasan masalah. Adapun batasan masalah pada penelitian ini adalah : 1) Ditinjau dari obyek penelitian, maka variabel bebas dalam penelitian ini terbatas pada pengembangan Kesenian Dongkrek melalui Media Komik Multimedia power point, sedangkan variabel terikatnya terbatas pada minat kemauan peserta didik SDN Bajulan Kecamatan Saradan memperlajari kesenian dongkrek. 2) Ditinjau dari subyek penelitian, maka penelitian dibatasi pada peserta didik SDN Bajulan Kecamatan Saradan. Berdasarkan latar belakang, identifikasi masalah, dan batasan masalah peneliti merumuskan masalah sebagai berikut: 1) Bagaimanakah pengembangan media sosialisasi nilai Kesenian Dongkrek menggunakan multimedia dengan powerpoint pada peserta didik dalam mengenal Kesenian Dongkrek sebagai icon Kabupaten Madiun di SDN Bajulan?, 2)Apakah sosialisasi nilai kesenian dongkrek dengan menggunakan multimedia power point pada peserta didik SD N Bajulan dapat berjalan secara Efektif? Adapun manfaat yang dapat diambil dari penelitian ini adalah dapat memberikan manfaat baik yang bersifat teoritis dan praktis. Pengembangan media komik berbasis multimedia dengan powerpoint dapat menjadi pendukung teori dan sosialisasi pada pengenalan ilmu sosial budaya daerah mulai dari dini.

\section{METODE PENELITIAN}

Penelitian ini menggunakan metode RnD, karena diarahkan kepada usaha untuk menghasilkan produk tertentu, dan menguji keefektifan produk tersebut.Penelitian ini dilaksanakan di SD Negeri Bajulan Kecamatan Saradan. Peneliti memilih sekolah ini karena tersedia sejumlah data yang mendukung serta beberapa alasan, yaitu Terpenuhinya kriteria sampel dan populasi yang sesuai dengan tujuan penelitian. Dan sekolah ini merupakan sekolah Model yang ada di Kecamatan Saradan, Sekolah Dasar Negeri Bajulan Kecamatan Saradan Kabupaten Madiun kecenderungan masih lebih memilih mendalami kesenian yang bukan merupakan kebudayaan asli dari Kecamatan Mejayan dan Khas Kabupaten Madiun. Karena memang ketersediaan alatnya. Teknik pengumpulan data yang digunakan untuk memperoleh data yang diperlukan baik yang berhubungan dengan studi pustaka maupun data yang dihasilkan dari data empiris. Yang menjadi istrumen pokok dalam penelitian R\&D adalah 
peneliti sendiri. Menggunakan validasi kelayakan, angket respon, observasi dan pengamatan, wawancara, sera dokumentasi. Teknik analisis data yang digunakan disesuaikan dengan jenis data dikumpulkan. Data yang diperoleh selama penelitian dianalisis dan diorientasikan untuk menyempurnakan model internalisasi nilai kesenian sehingga dapat dihasilkan model yang tepat untuk meningkatkan ketahanan budaya.

Prosedur penelitian yang akan dilaksanakan secara keseluruhan direncanakan sebagai berikut:

1. Tahap pra lapangan/persiapan

a. Menyusun proposal

b. Menentukan lapangan/tempat penelitian

c. Mengurus ijin penelitian

d. Survey, dengan tujuan untuk mengenal karakteristik, metode, memilih informan

e. Menyiapkan perlengkapan, yaitu menyusun jadwal penelitian, pedoman pengumpulan data, daftar pertanyaan, dan petunjuk observasi.

2. Tahap lapangan/pengumpulan data

a. Persiapan diri dengan menyiapkan penampilan dan memperkenalkan diri.

b. Mengumpulkan data di lokasi penelitian dengan melakukan observasi, wawancara, mencatat kejadian, dan memeriksa dokumen.

c. Melakukan review dan pembahasan atau menganalisa data atau informasi yang terkumpul dengan melaksanakan refleksi.

d. Mengatur data dalam kelompok untuk kepentingan analis dengan memperhatikan semua variabel yang terlibat.

3. Menyusun laporan penelitian

a. Menyusun laporan awal.

b. Review laporan, dengan cara berdiskusi dengan stake holder atau orang yang memahami permasalahan penelitian untuk perbaikan laporan sementara yang telah disusun.

Perbaikan laporan, kemudian disusun sebagai laporan akhir.

\section{HASIL DAN PEMBAHASAN}

Kesenian Dongkrek merupakan seni perpaduan antara seni tari, seni, musik, seni topeng, dan seni ceritera (drama) yang biasanya dipertunjukan dengan arak-arakan keliling kampung. Kesenian Dongkrek yang berupa arak-arakan biasanya melibatkan masyarakat bukan sebagai penonton tetapi sebagai pelaku budaya turut menari.

Asal-usul kesenian Dongrek menurut Wahyuningsih dkk (2012) dapat dirunut melalui tembang gambuh:

Keparengo amatur// Sekar gambuh amurwani atur//Seni dongkrek angirto dongkrek kang asli// Ngleluri budoyo luhung// Ciptane leluhur kito Semangke kang cinatur// Riwayat dongkrek engkang asli// Asal saking Dusun Menjayan kang asli// Palang kaleng-gahanipun// Priyo luhur kang yosoJamane kang kapungkur// Duk semono Menjayan kang usun// Katrajang eng pagablug akeh pepati// Tambah-tambah polah ipun//Kawulo ngudi usodo Berkah kang Moho Agung// Eyang Palang hang sakti kalangkung// Metu broto angento dongkrek mauwarni// Kinaryo mbrasto pageblug// Serno tapis tanpo siso Suko sukur yang Agung// Poro kawulo bingah kalangkung// Eyang Palang aparing dawuh sayekti// Istinen budoyo luhung// Nirkolo suko raharjo.

Walaupun pertunjukan kesenian Dongkrek memiliki sifat yang berbeda-beda sebagaimana yang disampaikan di atas namun masih memiliki nilai budaya yang sama yaitu kejahatan akan kalah dengan kebajikan, sura dira jayaningrat lebur dening pangastuti (semua perbuatan jahat akan kalah oleh perbuatan yang baik dan bijaksana). 
Nilai budaya kesenian Dongkrek tidak hanya terpotret pada framen cerita dramanya saja tetapi juga pada mkana topeng yang dikenakan ketika pelaksanakan pertunjukan. Topeng sebagai ilustrasi watak dari perilakunya yang dimaksud yaitu:

Topeng Raden Prawirodipura
Menggambar watak ksatria, bijak, dan kuat lahir-batin
Topeng Roro Ayu
Menggambarkan wanita yang cantik (putri pejabat) yang anggun, sopan
Talam berbicara, perilaku, dan selalu berbuat kebaikan
Menggambarkan wajah dari abdi kinasih (pengikut setia) Raden
Prawirodipoero yang berwatak ajeg atau berpendirian teguh tidak mudah
terpengaruh oleh orang lain, kemampuan yang dimilikinya, pantang
menyerah dapat diandalkan, juga sangat setia.

Topeng Genderuwa Merah.
Menggambarkan watak yang mudah marah, emosional, kasar, kaku dan suka
membuat masalah dengan yang lainnya.

Topeng Genderuwo Putih
Menggambar watak yang baik, memiliki tatakrama dan manusiawi. Warna
bersih, ternih dan menyucikan.

Topeng Genderuwo Hijau
Menggambar watak yang hampir sama dengan genderuwo hijau, ksatria,
berani bertanggung jawab, santun, namun hanya sebagai penutup atas
kemegahan dan kemewahan atas keberadaan harta dan benda.

Wewarah 


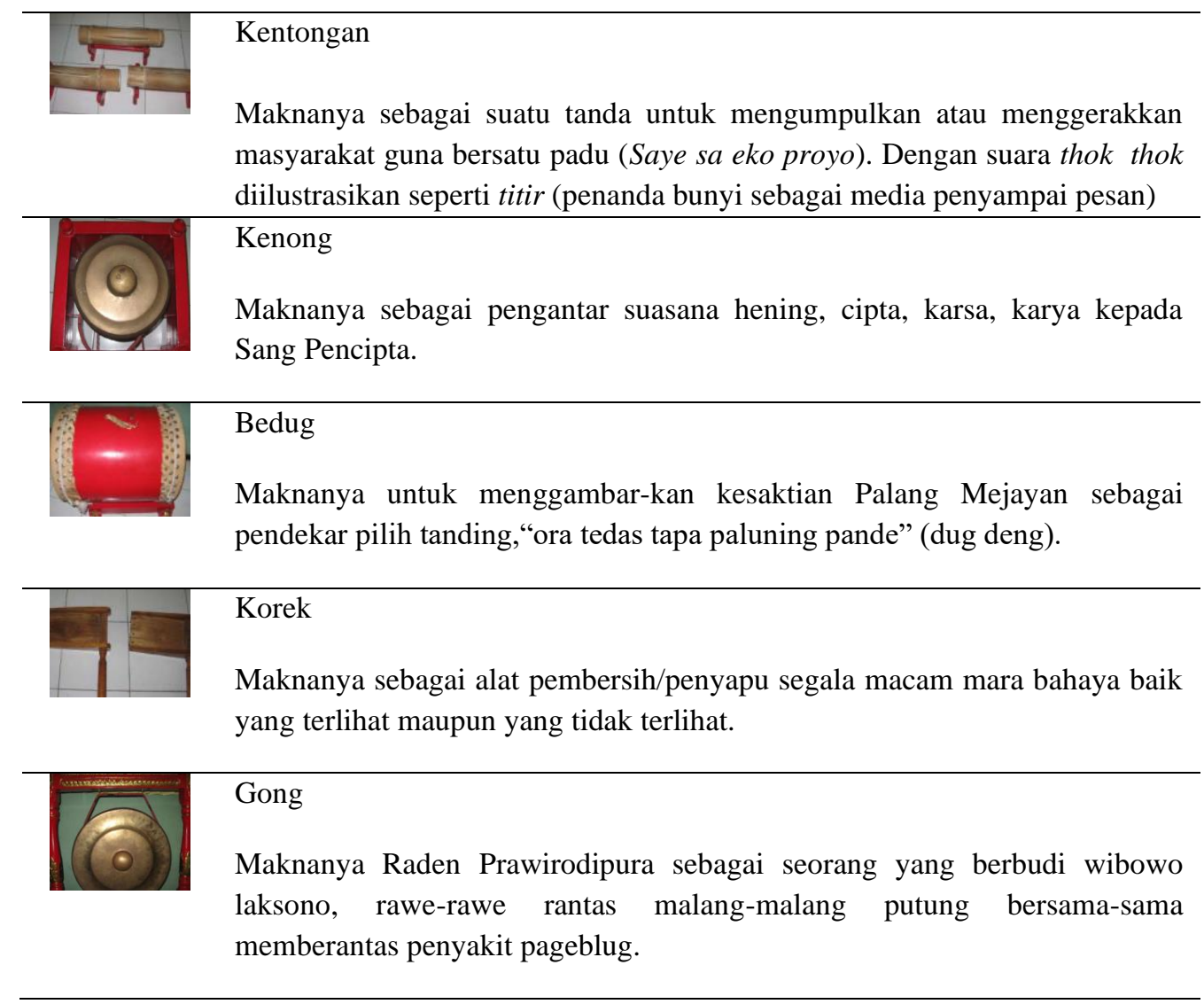

GAMBAR 1. Bentuk Topeng dan Alat Musik

Makna dari topeng di atas sejalan dengan hasil temuan Cahyani (2015) bahwa karakter pelaku dalam cerita dongrek diilustrasikan dalam perwajahan topeng yang mencerminkan watak atau karakter aktornya. Nilai-nilai kesenian dongkrek yang ditemukan dalam penelitian ini tidak beda jauh dengan hasil penelitian Hartini (2012). Bahkan jika ditelaah lebih dalam nilai--nilai dalam kesenian dongkrek sesuai dengan nilai-nilai Pancasila yaitu: (1) Kepercayaan sesuai dengan nilai ketuhanan, (2) Nilai kepribadian sesuai dengan nilai kemanusiaan, Nilai hiburan dan pertunjukan sesuai dengan nilai persatuan, (4) Nilai sosial atau kerukunan sesuai dengan nilai kerakyatan, (5) Nilai kesejahteraan dan kelestarian sesuai dengan nilai keadilan. Rosidi dan Fitroh meneliti niilai-nilai karakter yang didapat dalam cerita rakyat Banyuwangi. Temuannya antara lain nilai-nilai: "kerja keras, tanggung jawab, pengabdian, jujur, adil, dermawan, religius, bijaksana, gotong royong” (2020). Penelitian oleh Prasetyo dan Kumalasari tentang tradisi Peusijeuk sebagai pembelajaran sejarah mendapati nilai-nilai: toleransi, religius, sosial dan kerjasama (Prasetyo \& Kumalasari, 2021).

Hasil penelitian tentang keefektifan media komik berbasis multimedia dengan powerpoint pada pengembangan kesenian dongkrek, meliputi: (1) Pengembangan media komik berbasis multimedia dengan powerpoint, (2) kelayakan media komik berbasis multimedia dengan powerpoint, (3) tanggapan siswa dan guru; (4) keefektifan media komik berbasis multimedia dengan powerpoint, dan (5) aktivitas siswa.

Ahli materi Sriatun S.Pd memberikan masukan untuk melengkapi media komik berbasis multimedia dengan powerpoint dengan musik yang sesuai. Musik dapat menarik perhatian siswa dan menumbuhkan rasa ingin tahu siswa tentang isi materi yang hendak ditampilkan. Media komik berbasis multimedia dengan powerpoint awalnya belum dilengkapi dengan musik, sehingga terkesan kurang menarik bagi siswa. 
Ahli bahasa Sudarti S.Pd. memberikan masukan untuk memperbaiki penulisan sapaan pada dialog komik karena belum sesuai dengan tata penulisan yang benar. Kata sapaan seharusnya menggunakan huruf kapital, contohnya sapaan "Kak" untuk kakak diawali dengan huruf kapital. Penggantian nama tokoh juga disarankan oleh ahli bahasa, karena dengan nama yang asing didengar siswa akan mempersulit siswa terfokus pada materi yang hendak disampaikan pada media komik berbasis multimedia dengan powerpoint. Nama tokoh yang diganti yaitu nama tokoh Sasi diganti dengan Nisa, dan nama tokoh Danu diganti dengan Budi.

Ahli media Drs Badrus Sholihin, M.M. memberikan masukan untuk memperbaiki penulisan "Dengan menggunakan media komik berbasis multimedia dengan powerpoint, siswa dapat, (1) memahami nilai kesenian dongkrek dengan benar, (2) mengidentifikasi pengaruh positif yang terkandung di dalam komik multimedia dengan benar, (3) mengidentifikasi pengaruh negatif dengan benar". Diganti dengan "(1) dengan menggunakan media komik berbasis multimedia dengan powerpoint, siswa dapat memahami nilai kesenian dongkrek dengan benar, (2) dengan menggunakan media komik berbasis multimedia dengan powerpoint, siswa dapat mengidentifikasi pengaruh positif hal yang terkandung dalam kesenian dongkrek dengan benar, (3) dengan menggunakan media komik berbasis multimedia dengan powerpoint, siswa dapat mengidentifikasi pengaruh negatif nilai kesenian dongkrek dengan benar."

Ahli media Verry Sanreggo Marhaena, A.Md.A.K. juga memberikan masukan untuk memperbaiki komposisi warna dan tata letak gambar pada media komik berbasis multimedia dengan powerpoint. Warna gambar pada media komik berbasis multimedia dengan powerpoint masih cenderung gelap dan letaknya kurang proporsional, sehingga kurang menarik. Selanjutnya direvisi menjadi warna-warna yang cerah dan meletakkan gambar di tengah sehingga tampilan lebih menarik dan tertata dengan rapi.

Hasil penelitian tentang keefektifan media komik berbasis multimedia dengan powerpoint pada pengembangan kesenian dongkrek, meliputi: (1) Pengembangan media komik berbasis multimedia dengan powerpoint, (2) kelayakan media komik berbasis multimedia dengan powerpoint, (3) tanggapan siswa dan guru; (4) keefektifan media komik berbasis multimedia dengan powerpoint, dan (5) aktivitas siswa. Kelayakan media komik berbasis multimedia dengan powerpoint dinilai oleh ahli materi, ahli bahasa dan ahli media dalam dua tahap. Tahap pertama terdapat 10 aspek penilaian. Untuk tim penilai yang pertama diambil dari guru SD Negeri Bajulan, yang merupakan Guru Prestasi Tingkat Kabupaten Madiun Sriatun, S.Pd. untuk menilai dari segi materi, Sudarti S.Pd. untuk menilai segi bahasa, Drs Badrus S.,M.M dan Verry Sanreggo M. A.Md.A.K. dari segi Media di dalam komik multimedia. Untuk penilai dari bahasa Rekapitulasi hasil penilaian media komik berbasis multimedia dengan powerpoint tahap pertama disajikan pada tabel berikut.

TABEL 1. Rekapitulasi Penilaian Kelayakan Media Komik Berbasis Multimedia dengan Powerpoint Tahap I

\begin{tabular}{|l|c|c|c|}
\hline \multicolumn{1}{|c|}{ Validator } & Jumlah Skor & Presentase & Kriteria \\
\hline Materi & 8 & $80 \%$ & Layak \\
\hline Bahasa & 9 & $90 \%$ & Sangat Layak \\
\hline Media & 9 & $90 \%$ & Sangat Layak \\
\hline
\end{tabular}

TABEL 2. Rekapitulasi Penilaian Kelayakan Isi, Penyajian dan Kebahasaan Tahap II

\begin{tabular}{|l|l|l|l|}
\hline Validator & Jumlah Skor & Presentase & Kriteria \\
\hline
\end{tabular}




\begin{tabular}{|c|c|c|c|}
\hline Materi & 39 & $97,5 \%$ & Sangat Layak \\
\hline Bahasa & 32 & $80 \%$ & Layak \\
\hline Media & 36 & $90 \%$ & Sangat Layak \\
\hline
\end{tabular}

Ada beberapa point dalam hasil dari rumusan masalah yang ditulis pada bab pertama.

\section{Point Pertama}

Dari rumusan masalah pertama muncul hasil media Pengembangan media sosialisasi komik berbasis multimedia dengan powerpoint pada nilai kesenian dongkrek yang dikembangkan, bersifat bagus atau berhasil sesuai dengan apa yang ditujukan. Peserta didik lebih tertarik dengan gambar dari komik multimedia tersebut meskipun bergaya lama namun dibuat bergerak sesuai dengan karakter dari kisah yang ada. Menurut penilaian ahli materi, ahli bahasa dan ahli media memenuhi kriteria layak pada komponen isi, kebahasaan dan penyajian. Karena terfokus dan terperinci dari rumusan masalah sehingga menghasilkan sedemikan.

\section{Point Kedua}

Dari rumusan masalah ke dua dihasilkan jawaban seperti berikut, Media komik berbasis multimedia dengan powerpoint efektif untuk digunakan pada pengembangan nilai kesenian dongkrek terhadap hasil belajar peserta didik. Penggunaan media komik berbasis multimedia dengan powerpoint dapat meningkatkan aktivitas siswa dalam pengembangan nilai yang terdapat pada kesenian dongkrek dengan kriteria sangat tinggi di kelas Atas siswa SD Negeri Bajulan Kec. Saradan Kab. Madiun.

Implikasi hasil penelitian meliputi implikasi teoritis, implikasi, praktis dan implikasi pedagogis.

\section{1) Implikasi Teoretis}

Media komik berbasis multimedia dengan powerpoint efektif digunakan pada pengembangan media sosialisasi nilai kesenian dongkrek pada peserta didik SD Negeri Bajulan.

\section{2) Implikasi Praktis}

Media komik berbasis multimedia dengan powerpoint efektif digunakan pada pengembangan kesenian dongkrek melalui power point, dengan demikian pengembangan media komik berbasis multimedia dengan powerpoint mampu membantu guru dalam menyampaikan kesenian tradisional khas mejayan yaitu dongkrek serta memotivasi guru untuk membuat media pembelajaran yang inovatif. Bagi siswa media komik berbasis multimedia dengan powepoint membantu dalam proses memahami materi pelajaran dan memicu keaktifan siswa selama proses pembelajaran, sedangkan bagi sekolah hasil penelitian ini mampu menumbuhkan kerjasama antar sesama guru dalam mengembvangkan kesenian dongkrek di wilayah sekitar kecamatan saradan khususnya di sekolah dasar sehingga mutu sekolah dapat meningkat.

\section{3) Implikasi Pedagogis}

Penelitian ini menunjukkan bahwa media komik berbasis multimedia dengan powerpoint efektif digunakan dalam pengembangan nilai kesenian dongkrek terhadap minat belajar siswa. Hasil tersebut 
menunjukkan bahwa media pembelajaran yang inovatif, mampu menarik minat belajar siswa, dan memicu keaktifan siswa dalam proses pembelajaran sehingga dapat meningkatkan hasil belajar siswa. Media komik berbasis multimedia dengan powerpoint dikembangkan dengan memperhatikan beberapa komponen yang telah divalidasi oleh ahlinya, sehingga menghasilkan media yang dapat menciptakan proses pembelajaran yang berkualitas yang mampu meningkatkan minat dan motivasi siswa serta peran aktif siswa dalam kegiatan pembelajaran.

\section{SIMPULAN}

Berdasarkan hasil penelitian tersebut nantinya akan dapat disimpulkan bahwa penggunaan media Komik yang berbasis Multimedia dengan powerpoint secara teoritis oleh para validator dinyatakan secara subtantif dan fleksibilitas struktur desain model termasuk kategori tinggi, valid, dan layak digunakan untuk meningkat ketahanan budaya siswa SD Negeri Bajulan Kecamatan Saradan Kabupaten Madiun.

Untuk meningkatkan kualitas pengembangan media sosialisasi kesenian dongkrek melalui gambar yang diciptakan dari komik multimedia dengan powerpoint dan supaya para kaula muda mampu tertarik dengan dongkrek dapat ditingkatkan penulis memberikan saran-saran sebagai berikut:

Dalam mengembangkan media komik berbasis multimedia dengan powerpoint dibutuhkan perencanaan yang matang diantaranya: (1) perencanaan komponen isi yang disesuaikan dengan materi pelajaran yang akan diajarkan, (2) komponen bahasa yang disesuaikan dengan tingkat perkembangan anak dan (3) komponen penyajian yang disesuaikan dengan karakteristik siswa, sehingga pembelajaran lebih bermakna.

\section{DAFTAR PUSTAKA}

Cahyani, I.D. (2015). Karakteristik Topeng Dongkrek Sanggar Krido Sakti di Kecamatan Mejayan Kabupaten Madiun, Jurnal Pendidikan Seni Rupa, Volume 3 Nomor 2 Tahun 2015. Surabaya: UNNESA

Hanif, M. (2016). Kesenian Dongkrek (Studi Nilai Budaya dan Potensinya Sebagai Sumber Pendidikan Karakter) dalam Gulawentah Jurnal Studi Sosial Volume 1 Nomor 1, desember 2016.

Hartini. (2012). Kajian Nilai, Fungsi, dan Makna yang terkandung dalam Seni Dongkrek, dalam Primiere Educandum, Jurnal Pendidikan Dasar dan Pembelajarannya. Volume 2 Nomor 2 Tahun 2012.

Hartini. (2012). Kajian Nilai, Fungsi, dan Makna yang Terkandung Dalam Seni Dongkrek, Premiere Educandum Jurnal Pendidikan Dasar dan Pembelajarannya Volume 2 Nomor 2/2012. Prodi PGSD IKIP PGRI MADIUN

Prasetyo, O., \& Kumalasari, D. (2021). Nilai-Nilai Tradisi Peusijuek Sebagai Pembelajaran Sejarah Berbasis Kearifan Lokal: Indonesia. Mudra Jurnal Seni Budaya, 36(3), 359-365. https://doi.org/10.31091/mudra.v36i3.1387

Rosidi, M. I., \& Fitroh, I. (2020). Nilai-Nilai Karakter dalam Cerita Rakyat Banyuwangi Serta Relevansinya Terhadap Pembelajaran Sejarah. HISTORIA : Jurnal Program Studi Pendidikan Sejarah, 8(2), 95-112. https://doi.org/10.24127/hj.v8i2.2924

Wahyuningsih, S., dkk. (2012) Revitalisasi Seni Pertunjukan Dongkrek sebagai Upaya Penguatan Identitas Daerah dan Pengembangan Aset Wisata Budaya di Kabupaten Madiun Jawa Timur. Laporan Hasil Penelitian. Surakarta: UNS

Widyananda. (2015). Perancangan Buku Ilustrasi Kesenian Dongkrek Madiun, dalam Saraswati, Jurnal Desain Komunikasi Sosial. ISI Yogyakarta. http://journal.isi.ac.id/index.php/ saraswati/article/view/1086 